\title{
Effect of Pruning with Paclobutrazol Application for Growth, Yield and Quality of Mango (Mangifera indica L.) C.V. Amrapali
}

\author{
T.K. Singh*, Divya Singh A.K. Jain and U.S. Bose \\ J.N. Krishi Vishwa Vidyalaya, College of Agriculture, Rewa (M.P.) 486001, India \\ *Corresponding author
}

\section{Keywords \\ Mango pruning, Growth yield and quality}

\section{Article Info}

Accepted:

08 July 2018

Available Online:

10 August 2018

\section{A B S T R A C T}

A long term experiment was conducted to Effect of pruning with paclobutrazol application for Growth, Yield and Quality of Mango (Mangifera indica L.) C.V. Amrapali was conducted during 2007-08 to 2014-15at Fruit Research Station Kuthulia farm, College of Agriculture, Rewa Under All India Coordinated Research Project on subtropical fruits. The experiment was laid out in Randomized Block Design (RBD) comprising 10 treatments, which were replicated thrice. The treatments were comprised of 3 pruning methods namely $\mathrm{M}_{0}$ : No pruning, $\mathrm{M}_{1}: 10 \mathrm{~cm}$ heading back to terminal shoots, $\mathrm{M}_{2}: 10 \mathrm{~cm}$ heading back to terminal shoots, and 2 levels Paclobutrazol treatments i.e. $\mathrm{P}_{0}$ : without paclobutrazol and $\mathrm{P}_{1}$ : standard dose of paclobutrazol. The results indicate that various pruning of high density planting level and use of paclobutrazol exhibited significant effect on canopy, yield and quality of the fruits. The maximum tree height $(7.10 \mathrm{~m}$, ) were observed in treatment $\mathrm{M}_{2} \mathrm{~F}_{2} \mathrm{~T}_{2}$ " $20 \mathrm{~cm}$ heading back to terminal shoots during rest period before the emergence of new growth biannual time" tree spread from E-W and N-S $(6.20 \mathrm{~m}$ and $6.17 \mathrm{~m})$, were observed with the treatments $\mathrm{M}_{0} \mathrm{~F}_{0} \mathrm{~T}_{0}$ control without paclobutrazole application (Table 1a), The higher fruit weight and pulp percentage (347.50 g and 72.30), were observed with the treatment $\mathrm{M}_{2} \mathrm{~F}_{2} \mathrm{~T}_{1}$ : " $20 \mathrm{~cm}$ heading back to terminal shoots during rest period before the emergence of new growth Annual time" The maximum Pulp percentage was recorded (71.85\%) in $\mathrm{M}_{2} \mathrm{~F}_{1} \mathrm{~T}_{2} 20 \mathrm{~cm}$ heading back to terminal shoots Immediately after fruit harvest (June-July) Biannual time. The Maximum Total Soluble Solid (TSS) and acidity percentage $\left(21.87^{\circ} \mathrm{B}\right.$ and 0.30$)$ were observed with the treatment $\mathrm{M}_{0} \mathrm{~F}_{0} \mathrm{~T}_{0}$ control with paclobutrazol application. The pooled mean of 8 years data clearly indicated that fruit yield tree $\mathrm{e}^{-1}$ and yield ha ${ }^{-1}$ (53.27 and $213.08 \mathrm{qt}$.) have been registered with the treatment of $\mathrm{M}_{0} \mathrm{~F}_{0} \mathrm{~T}_{0}$ :Control with paclobutrazol application. The benefit cost ratio was also found higher with this treatment 2.6 (hectare basis) has been observed with the treatment of No Pruning with Paclobutrazol application.

\section{Introduction}

Mango (Mangifera indica L.) is one of the most important commercial fruits of India which is being grown in India more than four thousand years has been a source of inspiration of other countries and is currently being grown in over 90 countries around the world. In Madhya Pradesh region, farmers' economy is better dependent on mango. 
However under changing climate Langra mango yield is not sure. India ranks first in mango production of total world production. It has always placed at the highest position. It is national fruit of India, which is most popular among the consumers. It has great adaptability, thrives in a wide range of climatic, and soil conditions. It's utilized at all stages of its development both in its immature and mature stages. In Madhya Pradesh region farmers economy is better dependent on mango.where it occupies an area of 2515.97 thousand hectare with total production of 18431.33 thousand million tons. In which Madhya Pradesh, occupies an area of 25.43 thousand hectare and production is 379.73 thousand million tons (Anonymous 2013-14). In Rewa region has great potentially for mango cultivation is 7262 hectare. The success of mango cultivation largely depends on the soil, nutrient management etc. Actually soil is not an inert medium of plant growth as people often believe. The soil can influence of root growth, impact functional activities of plant and control the availability of nutrients. Nutrition consumption an important component of intensive cultivation of mango. An inadequate nutrition of mango orchard is one of the major constraints limiting the productivity. In Madhya Pradesh region farmers economy is better dependent on mango. However under changing climate hybrid Amrapali mango yield is sure. To overcome this High density planting in mango, HDP (2.5 x $2.5 \mathrm{~m})$ appears to the most appropriate answer to overcome high productivity and yield is continue long period. But due to hot and humid conditions tree put forth vegetative flushes in a year. Once the tree has occupied their allotted spaces, crowding may occur and canopies of an adjacent tree begin to overlap. Hence, to restrain the exuberant vegetative growth of mangoes to manageable sizes and forms thereby to achieve optimum production, to increase productivity of orchards and to stimulate precocious flowering, different pruning strategies were studied.

\section{Materials and Methods}

The field experiment was laid out in 2007 on 15 years old cv. Amrapali with the objectives to standardize level of pruning intensity for high density planting increasing the productivity of mango tree and to determine the effect of paclobutrazol on productivity and quality of mango fruits. The experiment was laid out in Randomized Block Design (RBD) comprising 10 treatments, which were replicated thrice. The plant grown at a distance of $2.5 \times 2.5 \mathrm{~m}$. The treatments were comprised of 3 pruning methods namely $\mathrm{M}_{0}$ : No pruning, $\mathrm{M}_{1}$ : $10 \mathrm{~cm}$ heading back to terminal shoots, $\mathrm{M}_{2}$ : $10 \mathrm{~cm}$ heading back to terminal shoots, and 2 levels Paclobutrazol treatments i.e. $\mathrm{P}_{0}$ : without paclobutrazol and $\mathrm{P}_{1}$ : standard dose of paclobutrazol. Thus, the ten treatment combinations $\quad\left(\mathrm{M}_{1} \mathrm{~F}_{1} \mathrm{~T}, \quad \mathrm{M}_{1} \mathrm{~F}_{2} \mathrm{~T}_{1}, \mathrm{M}_{1} \mathrm{~F}_{1} \mathrm{~T}_{2}\right.$, $\mathrm{M}_{1} \mathrm{~F}_{2} \mathrm{~T}_{2}, \quad \mathrm{M}_{2} \mathrm{~F}_{1} \mathrm{~T}_{1}, \mathrm{M}_{2} \mathrm{~F}_{2} \mathrm{~T}_{1}, \mathrm{M}_{2} \mathrm{~F}_{1} \mathrm{~T}_{2}, \quad \mathrm{M}_{2} \mathrm{~F}_{2} \mathrm{~T}_{2}$, $\mathrm{M}_{0} \mathrm{~F}_{0} \mathrm{~T}_{0}$, (without pp 333), $\left(\mathrm{M}_{0} \mathrm{~F}_{0} \mathrm{~T}_{0, \text { ) }}\right.$ (with pp 333), were imposed during rest period before the initiation of new growth. Data were recorded on tree height, trunk girth, canopy height, tree spread, yield tree ${ }^{-1}$, yield $\mathrm{ha}^{-1}$, fruit weight, pulp $\%$, stone $\%$, peel $\%$, total soluble solids, acidity and benefit: cost ratio of different treatments. The experimental unit, consisted of three trees, were randomly either treated with PBZ or left un-treated in a randomized complete block design with three replications. Paclobutrazol $(25 \%$ active ingredient) was applied as soil drenching at the rate of $2.5 \mathrm{~g} \mathrm{a.i} / \mathrm{m}^{2}$ followed by application of sufficient irrigation water and irrigation was withhold thereafter for three weeks. The fruits of each tree under study were picked of the commercial maturity stage on $15^{\text {th }}$ July. Titrable acidity was determined by the titration method with $0.1 \mathrm{~N} \mathrm{NaOH}$ up to ph 8.1 using $2 \mathrm{~g}$ of homogenized pulp in $100 \mathrm{ml}$ distilled water the results were expressed as 
percentage. The fruit length and width were measured by digital Verniercalipers and expressed in centimeters $(\mathrm{cm})$. The pulp percentage was calculated by considering the fruit, peel and stone weight. Total soluble solids (TSS) were determined using a Fisher hand refractometer at $20 \mathrm{c}^{0}$ and results were expressed as ${ }^{0} \mathrm{~B}$.

\section{Results and Discussion}

The results indicate that various pruning of high density planting level and use of paclobutrazol exhibited significant effect on canopy, yield and quality of the fruits. The maximum tree height $(7.10 \mathrm{~m})$ were observed in treatment $\mathrm{M}_{2} \mathrm{~F}_{2} \mathrm{~T}_{2}$ " $20 \mathrm{~cm}$ heading back to terminal shoots during rest period before the emergence of new growth biannual time" (Davenport, 2007). Tree spread from E-W and $\mathrm{N}-\mathrm{S}(6.20 \mathrm{mand} 6.17 \mathrm{~m})$, were observed with the treatments $\mathrm{M}_{0} \mathrm{~F}_{0} \mathrm{~T}_{0}$ "control without paclobutrazole application (Table 1a),
Maximum canopy height $(6.86 \mathrm{~m})$ was recorded in $\mathrm{M}_{2} \mathrm{~F}_{2} \mathrm{~T}_{2}$ " $20 \mathrm{~cm}$ heading back to terminal shoots during rest period before the emergence of new growth biannual time (Blaikie et al., 2004, and Kulkarni et al., 2006). The higher fruit weight and pulp percentage (347.50 $\mathrm{g}$ and 72.30), were observed with the treatment $\mathrm{M}_{2} \mathrm{~F}_{2} \mathrm{~T}_{1}$ : " $20 \mathrm{~cm}$ heading back to terminal shoots during rest period before the emergence of new growth Annual time and followed by (344.33g) was recorded in $\mathrm{M}_{0} \mathrm{~F}_{0} \mathrm{~T}_{0}$ control without paclobutrazole application" (Tandel and Patel, 2011 and Rahim et al., 2011). The Maximum Total Soluble Solid (TSS) (22.00B) was recorded $\quad \mathrm{M}_{0} \mathrm{~F}_{0} \quad \mathrm{~T}_{0}$ : control without paclobutrazol application and followed by (21.870B) was recorded $\mathrm{M}_{0} \mathrm{~F}_{0} \mathrm{~T}_{0}$ control with paclobutrazol application acidity percentage $\left(21.87^{\circ} \mathrm{B}\right.$ and 0.30$)$ were observed with the treatment $\mathrm{M}_{0} \mathrm{~F}_{0} \mathrm{~T}_{0}$ : control with paclobutrazol application (Matrnez et al., 2008).

Table 1(a) Effect of pruning on growth of mango cv. Amrapali during 2014-15

\begin{tabular}{|l|l|l|l|l|l|l|l|}
\hline S.No & Treatments & $\begin{array}{l}\text { Plant height } \\
(\mathrm{m})\end{array}$ & $\begin{array}{l}\text { Canopy } \\
\text { height }(\mathrm{m})\end{array}$ & $\begin{array}{l}\text { Root } \\
\text { stock }\end{array}$ & Scion & N-S & E-W \\
\hline $\mathbf{1}$ & $\mathrm{M}_{1} \mathrm{~F}_{1} \mathrm{~T}_{1}$ & 6.99 & 6.31 & 84.52 & 70.27 & 6.22 & 5.76 \\
\hline $\mathbf{2}$ & $\mathrm{M}_{1} \mathrm{~F}_{1} \mathrm{~T}_{2}$ & 6.91 & 6.06 & 76.11 & 65.76 & 5.63 & 5.52 \\
\hline $\mathbf{3}$ & $\mathrm{M}_{1} \mathrm{~F}_{2} \mathrm{~T}_{1}$ & 7.00 & 6.57 & 85.41 & 76.33 & 6.02 & 6.20 \\
\hline $\mathbf{4}$ & $\mathrm{M}_{1} \mathrm{~F}_{2} \mathrm{~T}_{2}$ & 6.83 & 5.95 & 94.71 & 69.66 & 6.07 & 5.91 \\
\hline $\mathbf{5}$ & $\mathrm{M}_{2} \mathrm{~F}_{1} \mathrm{~T}_{1}$ & 6.68 & 5.74 & 82.27 & 63.77 & 6.03 & 5.16 \\
\hline $\mathbf{6}$ & $\mathrm{M}_{2} \mathrm{~F}_{1} \mathrm{~T}_{2}$ & 6.78 & 6.19 & 80.81 & 75.52 & 6.07 & 5.45 \\
\hline $\mathbf{7}$ & $\mathrm{M}_{2} \mathrm{~F}_{2} \mathrm{~T}_{1}$ & 6.92 & 6.05 & 68.87 & 57.44 & 4.83 & 4.75 \\
\hline $\mathbf{8}$ & $\mathrm{M}_{2} \mathrm{~F}_{2} \mathrm{~T}_{2}$ & 7.10 & 6.86 & 81.11 & 71.07 & 6.33 & 5.73 \\
\hline $\mathbf{9}$ & $\mathrm{M}_{0} \mathrm{~F}_{0} \mathrm{~T}_{0}$ (without pp 333) & 6.65 & 5.94 & 78.08 & 65.57 & 6.17 & 5.27 \\
\hline $\mathbf{1 0}$ & $\mathrm{M}_{0} \mathrm{~F}_{0} \mathrm{~T}_{0}$ (with pp 333) & 7.05 & 6.36 & 89.77 & 79.91 & 6.45 & 6.04 \\
\hline & $\mathbf{S E M} \pm$ & $\mathbf{0 . 2 2 2}$ & $\mathbf{0 . 2 3 4}$ & $\mathbf{2 . 8 3 0}$ & $\mathbf{2 . 4 3 5}$ & $\mathbf{0 . 2 4 9}$ & $\mathbf{0 . 2 2 2}$ \\
\hline & $\mathbf{C D} @ \mathbf{5} \%$ & $\mathbf{0 . 7 0 2}$ & $\mathbf{0 . 7 3 9}$ & $\mathbf{8 . 9 1 6}$ & $\mathbf{7 . 6 7 2}$ & $\mathbf{0 . 7 8 3}$ & $\mathbf{0 . 7 0 1}$ \\
\hline
\end{tabular}


Table 1(c) Effect of pruning cummulative mean yield 8 year in HDP during 2007-08 to 2014-15

\begin{tabular}{|c|c|c|c|c|c|c|c|c|c|c|c|c|}
\hline S.No & Treatments & $\begin{array}{l}2007- \\
08\end{array}$ & $\begin{array}{l}2008- \\
09\end{array}$ & $\begin{array}{l}2009- \\
10\end{array}$ & 2010-11 & $\begin{array}{l}2011- \\
12\end{array}$ & $\begin{array}{l}2012- \\
13\end{array}$ & $\begin{array}{l}2013- \\
14\end{array}$ & $\begin{array}{l}2014- \\
15\end{array}$ & $\begin{array}{l}\text { Mean } \\
\text { Yield tree }^{-1}(\mathrm{~kg})\end{array}$ & $\begin{array}{l}\text { Yield } \text { ha }^{-1} \\
\text { (qt.) }\end{array}$ & $\begin{array}{l}\mathrm{B}: \mathrm{C} \\
\text { ratio }\end{array}$ \\
\hline 2 & $\mathrm{M}_{1} \mathrm{~F}_{1} \mathrm{~T}_{2}$ & 10.25 & 15.38 & 13.72 & 21.24 & 19.27 & 13.60 & 12.70 & 37.27 & 17.93 & 71.72 & 1.3 \\
\hline 3 & $\mathrm{M}_{1} \mathrm{~F}_{2} \mathrm{~T}_{1}$ & 8.60 & 13.00 & 12.18 & 36.15 & 38.17 & 15.27 & 14.90 & 38.41 & 22.09 & 88.34 & 1.6 \\
\hline 4 & $\mathrm{M}_{1} \mathrm{~F}_{2} \mathrm{~T}_{2}$ & 6.88 & 10.72 & 9.15 & 18.40 & 27.93 & 13.10 & 11.50 & 35.36 & 16.63 & 66.52 & 1.2 \\
\hline 6 & $\mathrm{M}_{2} \mathrm{~F}_{1} \mathrm{~T}_{2}$ & 9.00 & 14.00 & 12.07 & 15.87 & 17.57 & 19.93 & 18.20 & 45.76 & 19.05 & 76.20 & 1.4 \\
\hline 7 & $\mathrm{M}_{2} \mathrm{~F}_{2} \mathrm{~T}_{1}$ & 11.20 & 13.36 & 15.03 & 32.15 & 30.87 & 19.50 & 19.50 & 50 & 23.95 & 95.81 & 1.7 \\
\hline 8 & $\mathrm{M}_{2} \mathrm{~F}_{2} \mathrm{~T}_{2}$ & 7.92 & 12.00 & 12.31 & 25.90 & 27.97 & 20.00 & 18.00 & 49.33 & 21.68 & 86.72 & 1.6 \\
\hline 9 & $\begin{array}{l}\mathrm{M}_{0} \mathrm{~F}_{0} \mathrm{~T}_{0} \\
\text { (without pp } \\
\text { 333) }\end{array}$ & 25.10 & 39.24 & 30.53 & 16.35 & 17.73 & 12.27 & 11.00 & 87.27 & 29.94 & 119.75 & 2.1 \\
\hline \multirow{2}{*}{10} & S. Em \pm & 1.895 & 2.965 & 2.130 & 5.570 & 1.493 & 0.627 & 1.923 & 2.429 & & & \\
\hline & C.D. at $5 \%$ & 5.631 & 8.809 & 6.170 & 16.118 & 3.05 & 1,318 & 5.936 & 7.654 & & & \\
\hline
\end{tabular}


Table 1(b) Effect of pruning with paclobutrazol on physico-chemical of mango fruits during $2014-15$

\begin{tabular}{|l|l|l|l|l|l|l|l|}
\hline S.No & $\begin{array}{l}\text { Treatments } \\
\#\end{array}$ & $\begin{array}{l}\text { Fruit } \\
\text { weight }(\mathrm{g})\end{array}$ & $\begin{array}{l}\text { Peel } \\
\text { weight } \\
(\%)\end{array}$ & $\begin{array}{l}\text { Pulp } \\
\text { weight } \\
(\%)\end{array}$ & $\begin{array}{l}\text { Stone } \\
\text { weight } \\
(\%)\end{array}$ & $\begin{array}{l}\text { TSS } \\
\left({ }^{\circ} \mathrm{B}\right)\end{array}$ & $\begin{array}{l}\text { Acidity } \\
(\%)\end{array}$ \\
\hline $\mathbf{1}$ & $\mathrm{M}_{1} \mathrm{~F}_{1} \mathrm{~T}_{1}$ & 336.67 & 13.96 & 72.53 & 13.51 & 21.27 & 0.29 \\
\hline $\mathbf{2}$ & $\mathrm{M}_{1} \mathrm{~F}_{1} \mathrm{~T}_{2}$ & 340.67 & 13.87 & 72.67 & 13.47 & 21.50 & 0.29 \\
\hline $\mathbf{3}$ & $\mathrm{M}_{1} \mathrm{~F}_{2} \mathrm{~T}_{1}$ & 341.50 & 13.87 & 72.63 & 13.50 & 21.30 & 0.30 \\
\hline $\mathbf{4}$ & $\mathrm{M}_{1} \mathrm{~F}_{2} \mathrm{~T}_{2}$ & 339.33 & 13.53 & 72.43 & 14.03 & 21.47 & 0.29 \\
\hline $\mathbf{5}$ & $\mathrm{M}_{2} \mathrm{~F}_{1} \mathrm{~T}_{1}$ & 342.00 & 13.93 & 72.27 & 13.80 & 21.80 & 0.29 \\
\hline $\mathbf{6}$ & $\mathrm{M}_{2} \mathrm{~F}_{1} \mathrm{~T}_{2}$ & 340.86 & 13.87 & 71.85 & 14.29 & 21.47 & 0.30 \\
\hline $\mathbf{7}$ & $\mathrm{M}_{2} \mathrm{~F}_{2} \mathrm{~T}_{1}$ & 347.50 & 13.37 & 72.30 & 14.33 & 21.13 & 0.29 \\
\hline $\mathbf{8}$ & $\mathrm{M}_{2} \mathrm{~F}_{2} \mathrm{~T}_{2}$ & 343.33 & 13.43 & 72.33 & 14.23 & 21.47 & 0.30 \\
\hline 9 & $\begin{array}{l}\mathbf{M}_{\mathbf{0}} \mathbf{F}_{\mathbf{0}} \mathbf{T}_{\mathbf{0}} \text { (without } \\
\mathbf{p p} \mathbf{3 3 3})\end{array}$ & $\mathbf{3 4 3 . 6 7}$ & $\mathbf{1 3 . 4 0}$ & $\mathbf{7 2 . 3 7}$ & $\mathbf{1 4 . 2 3}$ & $\mathbf{2 2 . 0 0}$ & $\mathbf{0 . 2 9}$ \\
\hline $\mathbf{1 0}$ & $\begin{array}{l}\mathrm{M}_{0} \mathrm{~F}_{0} \mathrm{~T}_{0} \text { (with pp } \\
333)\end{array}$ & 344.33 & 13.27 & 72.17 & 14.57 & 21.87 & 0.30 \\
\hline & $\mathbf{S E M} \mathbf{S}$ & $\mathbf{0 . 2 2 2}$ & $\mathbf{0 . 2 3 4}$ & $\mathbf{0 . 2 3 0}$ & $\mathbf{0 . 1 3 5}$ & $\mathbf{0 . 2 4 9}$ & $\mathbf{0 . 0 0 5}$ \\
\hline & $\mathbf{C D}$ @ 5\% & $\mathbf{4 . 6 0 6}$ & $\mathbf{0 . 5 3 6}$ & $\mathbf{0 . 5 6 9}$ & $\mathbf{0 . 3 6 5}$ & $\mathbf{1 . 1 3 0}$ & $\mathbf{0 . 0 1 2}$ \\
\hline
\end{tabular}

The maximum peel weight percentage (13.96) was recorded in $\mathrm{M}_{1} \mathrm{~F}_{1} \mathrm{~T}_{1} 10 \mathrm{~cm}$ heading back to terminal shoots Immediately after fruit harvest (June-July) Annual time. Maximum Stone percentage (14.57) was observed $\mathrm{M}_{0} \mathrm{~F}_{0} \mathrm{~T}_{0}$ control without paclobutrazole application, (Table 1b). Here it is mention that the results related to vegetative parameters and physico-Chemical characteristics of fruits are on the basis of only 1 year data. The pooled mean of 8 years data clearly indicated that fruit yield tree ${ }^{-1}$ and yield ha ${ }^{-1}$ (53.27 and 213.08 qt.) have been registered with the treatment of $\mathrm{M}_{0} \mathrm{~F}_{0} \mathrm{~T}_{0}$ control with paclobutrazol application. The benefit cost ratio was also found higher with this treatment 2.6 (hectare basis) has been observed with the treatment of No Pruning with Paclobutrazol application (Balley I.S.E. 2000) and followed by $(29.94 \mathrm{~kg} / \mathrm{plant}$ and $119.75 \mathrm{qt})$ was recorded in $\mathrm{M}_{0} \mathrm{~F}_{0} \mathrm{~T}_{0}$ control without paclobutrazol application and benefit cost ratio with this treatment 2.1 has been observed (Winston, 1992). Evaluation of Paclobutrazol on growth showed better, are recommended for No Pruning with Paclobutrazol application for high density planting orchard to increase the productivity and quality of fruits as compared to other treatments in high density orchards of mango. (Table 1c).

\section{References}

Abdel Rahim A.O.S., Elamin O.M and Bangerth F.K. 2008. Effects of paclobutrazol on floral induction and correlated phyto-hormonal changes in grafted seedlings of different mango (Mangifera indica L.) cultivars. Sudan J. Agric. Res. 11: 111-120.

Adil.O.S,A. Rahim, O.M.Elamin and F.K Bangerth,2011.Effect of paclobutrazol on floral induction and associated 
hormonal and metallic changes of biennially bearing mango (Mangifera indica L.) cultivar during off year. ARPN Journal of Agricultural and biological Science 6(2) 55-67.

Balley I.S.E., Haris M. and Whiley A.W. 2000. Effect of water stress on flowering and yield of 'Kensington Pride' mango (Mangifera indica L.). Acta Horticulturae. 509: 277-281.

Blaikie S.J., Kulkarni V.J. and Muller W.J. 2004. Effect of morphactin and paclobutrazol flowering treatments on shoot and root phenology in mango cv. Kensington Pride. Scientia Horticulturae. 101: 51-68.

Davenport T.L. 2007. Reproductive physiology of mango. Braz. J. Plant Physiol. 19(4): 363-376.

Engels C., Knodler M, Zhao. Y Carle R., Ganzle M.G., Schieber A. Antimicrobial activity of gallotannins isolated from mango (Mangefera indica L.) Kernels, J. Agric. Food chem., 57(2009). 7712-7718.

Kulkarni V.D Hamilthon and GMC Mahon, 2006. Flowering and fruiting in Mangoes in top end with Paclobutrazol. Crop Forestry and horticulture, Darwin DPIFM, No. ND 20 September 2006.

Matrnez, A.R, A.L.A. Perez and J.R. Mereno. 2008. Effect of paclobutrazol and $\mathrm{KNO}_{3}$ over flowering and fruit quality in two cultivars of Mango Manila Inercenia. 33(7): 518-522.

Tandel,Y.N and N.L Patel,2011. Effect of chemical on growth, yield and economics of mango Mangiferaa indica L.) Karnataka, J. Agric. Sci., 24(3): 362-365.

Winston E.C. 1992. Evaluation of Paclobutrazol on growth, flowering, and yield of mango cv. Kensington pride. Aust. J. Exp. Agric. 32: 97-104.

\section{How to cite this article:}

Singh, T.K., Divya Singh A.K. Jain and Bose, U.S. 2018. Effect of Pruning with Paclobutrazol Application for Growth, Yield and Quality of Mango (Mangifera indica L.) C.V. Amrapali. Int.J.Curr.Microbiol.App.Sci. 7(08): 883-888. doi: https://doi.org/10.20546/ijcmas.2018.708.100 